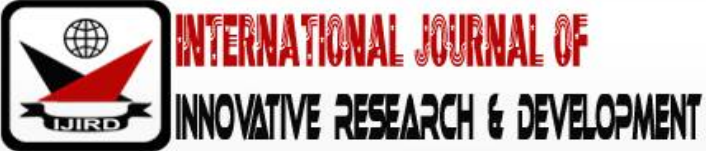

ISSN 2278 - 0211 (Online)

\section{The Nexus between Girl-Child Education and Women Economic Empowerment in Ikot Ekpene Local Government Area, Akwa Ibom State, Nigeria}

\author{
Ufot-Akpabio, Akpabio M.
Lecturer, Department of Urban \& Regional Planning, University of Uyo, Uyo, Nigeria
Udoyen, Grace J
Director, Graz Centre for Gender Studies, Port-Harcourt, Rivers State, Nigeria
Ofem, Ijeoma B.
Lecturer, Department of Educational Technology and Library Science, University of Uyo, Nigeria
}

\begin{abstract}
:
This study was carried out to examine the link between girl-child education and women economic empowerment in Ikot Ekpene Local Government Area of Akwa Ibom State, Nigeria, in view of the observed impediments to girl-child education and by extension women low involvement in various sectors of the society. Specific objectives of the study were to examine how girl-child education influences women involvement in technical occupation, investigation of the link between girl-child education and women access to credit facilities and to examine the relationship between girlchild education and land ownership in the aforementioned area. The research questions were formulated to guide the study. The sampled size of Two Hundred and Sixty-four (264) persons (household heads) were obtained from the twenty-two communities sampled using random sampling technique. The instrument was face and content-validated and reliability coefficient of 0.884 was obtained using Cronbach Alpha. The study adopted a cross-sectional research design while field data were analysed using Means, Standard Deviation and chi-square (X2). The study revealed among other things that there is a positive association between girl-child education and women engagement in technical occupation, exposure to credit facilities and other related financial services and by extension women economic empowerment in the study area. The study recommends increase attention to gender equality and other factors hindering girl-child education in the study area.
\end{abstract}

Keywords: Akwa Ibom State, Girl-child education, Ikot Ekpene LGA, Nigeria, women economic empowerment

\section{Introduction}

Education is the key responsibility of governments the world over, and when government at any level fails to invest adequately in the educational system it fails, and the quality of education dwindles, socio-economic, political, and technological attainment of the citizenry and the nation suffers. The enhancement of quality of lives, increase economic growth, harnessing of human intellect and potentials, realization of political stability, appreciation of tolerance, strengthening of institution of peace and unity depends largely on education (United Nations, 2013). Offorma (2009) considered education as a process through which the young acquire knowledge, realize their potentials and use them for self-actualization. It is also a means through which individuals (young and adult) are made to function responsibly in the society (Ocho, 2015). Education can also be viewed as an instrument for building one's personality, relax, organize ones live and equipped to achieve one's basic rights. Education does not only imply collecting some factual information, rather it is actual learning to deal with the practicalities of life, to live with other people practically and how to adjust oneself to relate with other people (Ashraf, 2007).

For education to achieve the set goals, it must be 'quality' and include a gender perspective (Lifanda, 2005). Quality education must offer everyone access to it and must be appropriated for the development of their full capacity to be responsible for themselves as well as participate in public life. It must recognize and acknowledge gender differentials and provide the foundation upon which differences must be met or addressed. Lifanda (2005) asserted that once education has positive impact on the lives of a girl-child and women it can rightly be termed quality education and it would definitely have good impact on outcomes.

According to Huzeru (2012), girl-child reflects childhood of age ranging between 0-18 years. Offorma (2009) saw the girl-child as a biological female from birth to 18 years which include infancy, childhood, early and late adolescence stages of development. The transition of girl-child to a safe, healthy and more productive adulthood in contemporary era can be seen to be a function of quality education. In most developing nations including Nigeria, adolescent girls are underserved by the education sector. Many girl-children in Nigeria, Akwa Ibom State (AKS) and Ikot Ekpene in particular 
are not in school, those in school are not receiving quality/relevant education (formal or informal) in a save and supportive environment.

Sub-Sahara Africa including Nigeria, accounts for about $75 \%$ out of 121 million girls that are out of school the world over (UNICEF, 2015). UNESCO (2013) noted that 31 million girls of primary school age are out of school and of this figure, 17 million have never been to school. In Nigeria, it was reported that about 5.5 million girls are not in school. In the lower secondary school, 34 million girls are missing the chance of acquiring skills for social, economic, political empowerment and development (NBS, 2015). Girl-child and woman can only achieve self-actualization in Nigeria through quality education, as this will give her the needed empowerment to unproven her status in all spheres of life.

Empowerment in the context of this study connotes socio-economic power, and self-discovery. It is a personal and social change that occur and enforce psychological, political, social and economic domains through which women assumed power, meaningful choices and control over their lives (Ekesionye\&Okolo, 2012; 0'Neilet al.,2014; Channawar, 2019). Empowerment cannot take place unless women's reproductive responsibility is adequately compensated or shared with men. It is proper to understand that policies often times have different outcomes on women due to the nature of their relations with men.

In developing nations inducing Nigeria women's empowerment now includes women gaining control over their own lives by expanding choices, this entails resolving conflict between women's productive and reproductive roles with men. (Nazet al., 2013;Udoyenet al., 2017) asserted that gender, inequality, and power imbalances that characterized sexual relationship are inextricably linked to the limited educational and training opportunitiesfor women, which results in the continuous dependence on men.

Increase access of women to development resources, increases their productivity and stimulates development. When women are educated, their children are healthier, population growth rate decreases and increase in production leads to higher standards of living for everyone. But exclusion or limiting women from gaining access to development not only leaves women worse off, but impoverishes not only the women but the entire society.

It is on these premises that (World Bank, 2013;Fox \&Romero, 2017) posited that women economic empowerment is predicated on increase investment in girls-child (women) education. In this study, the essence for girl-child (woman) education as well as their economic empowerment in the overall development matrix in Ikot EkpeneLGA, Akwa Ibom State, Nigeria was examined.

\section{The Problem}

Education is a significant factor in the development and harnessing of human resource. It is globally acknowledged as a human right comprising significant components of opportunities needed for women empowerment (Chandhry \& Rahman, 2009). Improvement and development in social, economic, political and technological life of the society involve granting the girl-child (women) equal access to quality education in every community at all times. This is vital in empowering the girl-child to enjoy her Human Right (Lagachu, 2016). According to UNESCO (2013), half the population in the world consists of women who constitute two-thirds of the world's labour, earn one-tenth of the world's income and own one-hundredth of the world's property including land. In Nigeria, they constitute almost half of the population (49\%) and by extension $65.1 \%$ of the work force (NBS, 2015). Despite women contribution to all facets of the economy, they usually encounter discrimination in all aspect of life. This discrimination manifests in low primary and secondary school enrolment, $48.6 \%$ and $45.7 \%$ respectively in 2015 , employment, governance, leadership and in micro and macro-economic environment. These challenges are as a result of the way the society is structured and functions on the basis of gender (Nazet al., 2013; Udoyenet al., 2017).

UN (2013) also stressed that if women are given the same access as men to productive assets that agricultural output in thirty-four (34) developing nations would rise by an estimate of four percent (4\%). Several studies in developed and developing societies indicate that a vibrant, healthy and economically developed societies depend to a greater extent on the quality of formal education of women, as educated women have greater propensity for economic mobility. In spite of these overwhelming importance and acknowledgement of the girl-child (women) education in Nigeria as in other parts of the world, barriers to girl-child education are yet to be adequately addressed. This has resulted in most women constituting a bulk of underutilized economic resource in Nigeria and in the study area in particular.

In line with the above assertion, Doreen (2014) stated that no community will remain undeveloped if it has the required human capital, and the best instrument in this direction is investment in human capital which women are the major component. The acquisition of knowledge and technical skill (formal or informal) guarantees economic, social, political and technological liberation of individuals mostly women, and by implication enhance their contribution to the families, local and national development and growth. Also, as more girl-child (women) are educated, the more health of the family and society improves. With increase awareness of the need for education among the girl-child, there will be also an increase of women in the labour force; improvement in the protection of the environment and also improve agricultural practices (Ballara, 2002). The importance of education for the advancement of women was globally acknowledged in the Beijing conference (Beijing Platform for Action) which identified and affirmed it as central for gender equality and elimination of discrimination in education on the basis of gender at all levels and improving access of women to vocational training, science and technology, continuing education and eradicating illiteracy among women.

In Nigeria, AKS, and the study area, the concern for equality and educational attainment of women are as reflected in section 38 (1), Constitution of the Federal Republic of Nigeria, 1999 (as Amended), Domestication of Article 17 of Africa Charter on Human and People's Rights (Rectification and Empowerment) ACT, which guarantees equal right to education in Nigeria, initiation and implementation of various educational policies and programmes, such as national and state policies on education, Universal Basic Education (UBE), school feeding programme and collaboration with international 
donor agencies such as UNICEF and UNESCO in promoting girl-child education in the country. In AKS, where the study area is a component, these policies and programmes are in place including free education at the primary and junior secondary school levels for all irrespective of sex or gender. Thus, for any developing society or community such as Ikot EkpeneLGA to experience the needed women economic empowerment the girl-child must be given equal access just as men to quality education.

\section{The Study}

Against the stated background, the study aims to examine empirically the link between the girl-child education and women economic empowerment in Ikot Ekpene LGA, Akwa Ibom State, Nigeria.

The study sought to address the following objectives:

- Examine how girl-child education influences women involvement in technical occupation in the study area.

- Investigate the connection between girl-child education and women's access to credit facilities in Ikot EkpeneLGA.

- Examine the relationship between girl child education and land ownership in Ikot EkpeneLGA. To adequately address the set objectives, the following research questions were outlined:

- What is the difference between girl-child education and women involvement in technical occupation.

- To what extent do girl-child education influence women's ability to access credit facilities in the study area.

- What is the relationship between the girl-child education and women ownership of land in Ikot Ekpene LGA.

The study therefore is anchored on the following research hypotheses:

- $\mathrm{H}_{1}$ : Girl-child education has a significant relationship with women involvement in technical occupation.

- $\mathrm{H}_{2}$ : Girl-child education has a significant influence with women access to credit facilities.

- $\mathrm{H}_{3}$ : Girl-child education has a significant influence on the ownership of land.

\section{The Study Location}

Ikot EkpeneLGA is an urban area that situates on the upland part of the state. It is one of the thirty-one LGAs in Akwa Ibom State, Nigeria. It has a land area of $128 \mathrm{~km}^{2}$ a population of 172,821 people with density of $1350 \mathrm{~km}{ }^{2}(\mathrm{AKS}$., 2013). Geographically, it is situated between latitudes $4^{0} .8^{1}$ and $5^{0} 16^{1}$ East and longitudes $7^{0} 35^{1}$ and $7^{0} 16^{1}$ North of Greenwich (AKS, 2013). Climatically, the area falls within the humid tropics where heavy rainfall, high humidity and high temperature are the common characteristics. The vegetation is sparse with mainly shrubs, herbaceous weeds and trees due to uncontrolled and subsistence farming practices in the area. The area is acknowledged as the political,socioeconomic and cultural capital of the Annang ethnic group of the state.

The area occupies a prominent position in the contemporary Akwa Ibom State economic dynamics as the economy of the area is anchored principally on agriculture and commerce. Major agricultural produce in the area include palm products such as palm oil, kernel including fibres and wine. The area is dubbed 'The Raffia City' as it boasts of vibrant enterprises majoring on wood work, carving and raffia crafts and products such as raffia shoes/sandals, raffia portfolios, Ekpo and Ekpe dummies and lawyer wigs (Obot, 2006)for local and international markets. A home to many educational and socio-economic infrastructure that can promote girl-child (women) education and economic development in the area. Figure 1 shows the study area with sampled communities.

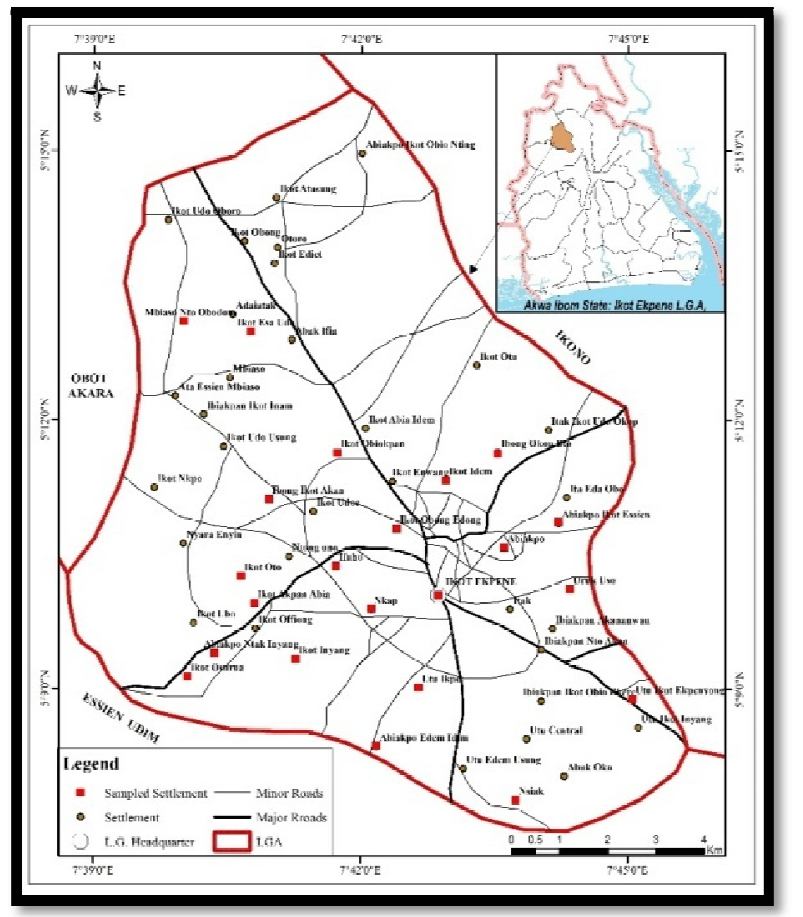

Figure 1: Ikot Ekpene L.G.A. Showing Sampled Communities Source: Field Survey, 2019 


\section{Methodology}

The study adopted a descriptive survey design which involves the application of appropriate quantitative approaches in gaining insight into the issues under investigation and collecting data that can be used to draw conclusion about the large population. Data from primary and secondary sources were drawn for the study.

The study population consisted of the total number of household heads (made and female) in the study area. Ikot Ekpene LGA is made up of sixty-five (65) gazetted villages (AKS., 2013). Udofia (2011), asserted that 10\% of total population is ideal for consideration for sampling, but for wide coverage of the study area 22(33.8\%) of the villages were considered for the study (Table 1 and Figure 1). In selecting the 22 villages, random sampling was carried out using table of random numbers. The number of households in each settlement was obtained by dividing the projected population by average household size of six (NPC, 1998), while the sample size for each village was obtained using the factor (264) obtained by using Yaro Yamene Formulae:

$$
\frac{\mathrm{N}=\mathrm{N}}{1+\mathrm{N}(\mathrm{e})^{2}}
$$

Where: $\mathrm{n}=$ the samples size, $\mathrm{N}=$ population size, $\mathrm{e}=$ level of significance and $\mathrm{I}=$ unity

\begin{tabular}{|c|c|c|c|c|c|}
\hline S/N & Name of Settlement & $\begin{array}{c}\mathbf{1 9 9 1} \\
\text { Census }\end{array}$ & $\begin{array}{c}\mathbf{2 0 1 9} \\
\text { Projections }\end{array}$ & $\begin{array}{c}\text { NO. of } \\
\text { Households }\end{array}$ & Sample Size \\
\hline 1. & Abiakpo Ikot ObioNting & 789 & 1136 & 189 & 3 \\
\hline 2. & Abiakpo Ikot Essien & 9650 & 24608 & 4101 & 57 \\
\hline 3. & AbiakpoNtak Inyang & 1663 & 2398 & 400 & 6 \\
\hline 4. & Abiakpo & 789 & 1136 & 189 & 3 \\
\hline 5. & GRA (Nkap) & 5294 & 13500 & 2250 & 32 \\
\hline 6. & Ibong Ikot Akan & 1817 & 2616 & 436 & 6 \\
\hline 7. & IbongOkopEto & 415 & 598 & 100 & 2 \\
\hline 8. & Ifuhu & 4814 & 12276 & 2046 & 30 \\
\hline 9. & Ikot Akpan Abia & 688 & 991 & 165 & 2 \\
\hline 10. & Ikot Osurua & 569 & 819 & 137 & 2 \\
\hline 11. & Ikot Ekpene & 695 & 1772 & 295 & 4 \\
\hline 12. & Ikot Idem & 368 & 530 & 88 & 2 \\
\hline 13. & Ikot Inyang & 1768 & 2546 & 424 & 6 \\
\hline 14. & Ikot ObioOkpon & 516 & 743 & 124 & 2 \\
\hline 15. & Ikot ObongEdong & 5700 & 14535 & 2423 & 34 \\
\hline 16. & Ikot Oto & 1070 & 1541 & 257 & 4 \\
\hline 17. & Ikot Usa Udo & 285 & 410 & 68 & 2 \\
\hline 18. & MbiasoNtoObodom & 501 & 721 & 120 & 2 \\
\hline 19. & Nsiak & 2257 & 3250 & 542 & 8 \\
\hline 20. & UrukUso & 8012 & 20431 & 3405 & 48 \\
\hline 21. & Utu Ikot Ekpeyong & 1473 & 2121 & 354 & 5 \\
\hline 22. & Utu Ikpe & 1090 & 1570 & 262 & 4 \\
\hline & Total & $\mathbf{5 0 , 2 2 3}$ & $\mathbf{1 1 0 , 2 4 8}$ & $\mathbf{1 8 , 3 7 5}$ & $\mathbf{2 6 4}$ \\
\hline
\end{tabular}

Table 1: Sample Communities and Size

Source: NPC, 1991, Authors' Computations (2019)

Information in the questionnaire was based on the objectives of the study. The research instrument was subjected to validity test and the outcome showed a high reliability (Cronbach Alpha) coefficient of 0.884 . The data collected were analysed using descriptive statistics and chi-square $\left(\mathrm{X}^{2}\right)$ statistical tools.

\section{Data Presentation}

A total of 264copies of questionnaires were distributed with 198 returned giving a return rate of $75 \%$. The returned questionnaire was scrutinized and 2 copies were rejected because of incomplete responses while 4 were not retrieved. The final 192 questionnaire (72.73\%) returned were considered to be representative of the sample and were used for the analysis.

\section{Results}

\begin{tabular}{|c|c|c|c|c|c|}
\hline \multicolumn{2}{|c|}{} & Frequency & Percent & $\begin{array}{c}\text { Valid } \\
\text { Percent }\end{array}$ & $\begin{array}{c}\text { Cumulative } \\
\text { Percent }\end{array}$ \\
\hline \multirow{3}{*}{ Valid } & Male & 84 & 43.8 & 43.8 & 43.8 \\
\cline { 2 - 6 } & Female & 108 & 56.3 & 56.3 & 100.0 \\
\cline { 2 - 6 } & Total & 192 & 100.0 & 100.0 & \\
\hline
\end{tabular}


Table 2 shows the sex distribution of respondents which weighs in favour of female with $56.3 \%$ while male was $43.8 \%$

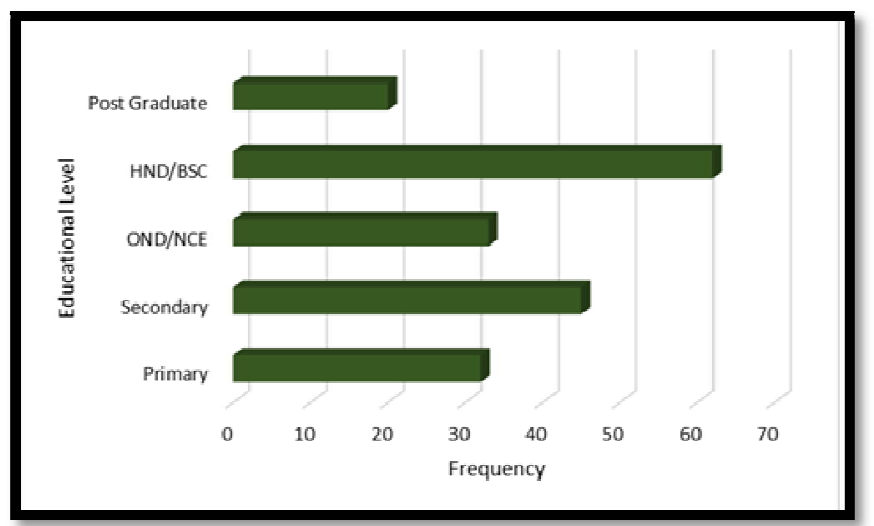

Figure 2: Level of Education of Respondents Sources: Field Survey, 2019

Educational qualification of participants shows that 16.75 had Primary School Leaving Certificate, 23.4\% Secondary Certificate, $17.2 \%$ Ordinary National Diploma/National Certificate of Education, 32.3\% Higher Degree Diploma/First Degree while $10.4 \%$ of them had Post Graduate Certificates.

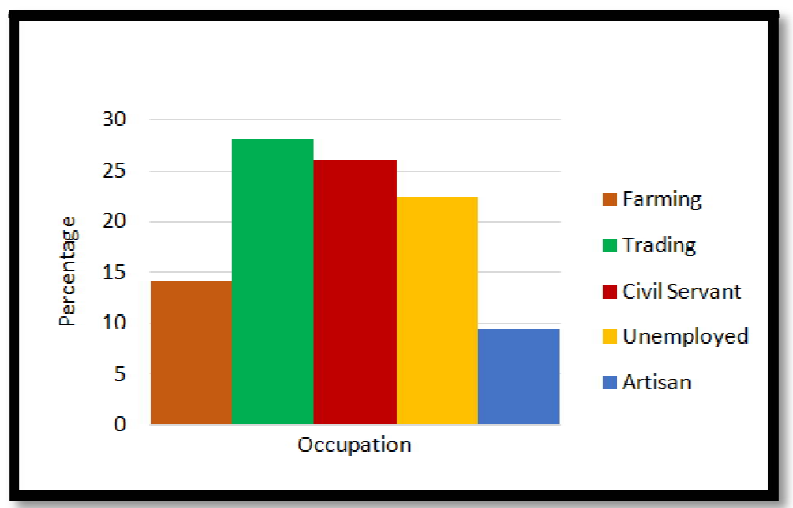

Figure 3: Occupational Status of Respondents Sources: Field Survey, 2019

Figure 3indicates the occupational distribution of respondents $41.1 \%$ engaged in farming, $28.1 \%$ trading, $26 \%$ civil servants, $22.4 \%$ were unemployed and only $9.4 \%$ were artisan.

\section{Analysis of Research Questions}

\subsection{Research Question 1}

What is the difference between girl-child education and women involvement in technical occupation?

\begin{tabular}{|c|c|c|c|c|c|c|c|c|}
\hline S/N & Statement & SA (\%) & A (\%) & DA (\%) & SD (\%) & Mean & Std. & Decision \\
\hline 1 & $\begin{array}{c}\text { Women with higher } \\
\text { education are } \\
\text { professionals }\end{array}$ & $87(45.3)$ & $65(33.9)$ & $19(9.9)$ & $21(10.9)$ & 3.14 & 0.99 & Agree \\
\hline 2 & $\begin{array}{c}\text { Girl child without } \\
\text { education are found in } \\
\text { the informal } \\
\text { employment }\end{array}$ & $72(37.5)$ & $83(43.2)$ & $20(10.4)$ & $17(8.9)$ & 3.09 & 0.91 & Agree \\
\hline 3 & $\begin{array}{c}\text { Education of the girl - } \\
\text { child increases her } \\
\text { chances in technical } \\
\text { occupation. }\end{array}$ & $73(38)$ & $96(50)$ & $14(7.3)$ & $9(4.7)$ & 3.21 & 0.77 & Agree \\
\hline & Total & $232(40.3)$ & $244(42.4)$ & $53(9.2)$ & $47(8.2)$ & 3.15 & 0.89 & Agree \\
\hline
\end{tabular}

Table 3: Responses on Girl-Child Education and Women Involvement in Technical Occupation

Source: Field Survey, 2019 
Table 3above shows that respondents agreed that women with higher education are professionals $(3.14 \pm 0.99)$. Also, they agreed that the girl-child without education is found on the informal employment (3.09 \pm 091$)$. They also agreed that education of the girl-child increases her chances in technical occupation (3.21 \pm 0.77$)$. The analysis shows that girlchild education influences involvement of women in technical occupation in Ikot Ekpene LGA, because the grand mean of 3.15 is greater than the criterion mean of 2.5 .

\subsection{Research Question 2}

To what extent does girl-child education influence women's ability to access credit facilities in IkotEkpene LGA.

\begin{tabular}{|c|c|c|c|c|c|c|c|c|}
\hline S/N & Statement & SA (\%) & A (\%) & DA (\%) & SD (\%) & Mean & Std. & Decision \\
\hline 1 & $\begin{array}{c}\text { Educated women } \\
\text { can borrow money } \\
\text { from banks }\end{array}$ & $75(39.1)$ & $67(34.9)$ & $34(17.7)$ & $16(8.3)$ & 3.05 & 0.95 & Agree \\
\hline 2 & $\begin{array}{c}\text { Girl child education } \\
\text { do not help in } \\
\text { acquiring loans }\end{array}$ & $57(29.7)$ & $69(35.9)$ & $38(19.8)$ & $28(14.6)$ & 2.81 & 1.02 & Agree \\
\hline 3 & $\begin{array}{c}\text { Girl child education } \\
\text { is an avenue for } \\
\text { obtaining credit } \\
\text { facilities }\end{array}$ & $53(27.6)$ & $56(29.2)$ & $47(24.5)$ & $36(18.8)$ & 2.66 & 1.08 & Agree \\
\hline & Total & $185(32.1)$ & $192(33.3)$ & $119(20.7)$ & $80(13.9)$ & 2.84 & 1.03 & Agree \\
\hline
\end{tabular}

Table 4: Responses on Girl-Child Education and Women's Ability to Access Credit Facilities

Source: Field Survey, 2019

The analysis of responses in Table 4 shows that respondents agreed that educated women can borrow money from banks $(3.05 \pm 0.95)$. They also agreed that in their community girl-child education is an avenue for obtaining credit facilities $(2.66 \pm 1.08)$. Respondents agreed that girl-child education does not help in acquiring loans $(2.81 \pm 1.02)$. Analysis of the question indicates that girl-child education influences women's ability to access credit facilities in the study area because the grand mean of 2.84 is greater than the criterion means of 2.5 .

\subsection{Research Question 3}

How does the girl-child education influence women ownership of land in Ikot Ekpene LGA?

\begin{tabular}{|c|c|c|c|c|c|c|c|c|}
\hline S/N & Statement & SA (\%) & A (\%) & DA (\%) & SD (\%) & Mean & Std. & Decision \\
\hline 1 & $\begin{array}{c}\text { The level of girl's } \\
\text { education is high in } \\
\text { this community }\end{array}$ & $21(10.9)$ & $35(18.2)$ & $75(39.1)$ & $61(31.8)$ & 2.08 & 0.97 & Disagree \\
\hline 2 & $\begin{array}{c}\text { In this community } \\
\text { girl child education } \\
\text { is important }\end{array}$ & $22(11.5)$ & $27(14.1)$ & $76(39.6)$ & $67(34.9)$ & 2.02 & 0.98 & Disagree \\
\hline 3 & $\begin{array}{c}\text { The girl child in this } \\
\text { community is seen } \\
\text { as an asset }\end{array}$ & $22(11.5)$ & $24(12.5)$ & $81(42.2)$ & $65(33.9)$ & 2.02 & 0.96 & Disagree \\
\hline 4 & $\begin{array}{c}\text { Girl child education } \\
\text { facilitate land } \\
\text { ownership }\end{array}$ & $18(9.4)$ & $35(18.2)$ & $65(33.9)$ & $74(38.5)$ & 1.98 & 0.97 & Disagree \\
\hline Total & $83(10.8)$ & $121(15.8)$ & $297(38.7)$ & $267(34.8)$ & 2.03 & 0.97 & Disagree \\
\hline
\end{tabular}

Table 5: Responses on Girl-Child Education and Women Ownership of Land Source: Field Survey, 2019

Table 5 shows that respondents disagreed that the level of girl education is high in their community (2.08 \pm 0.97$)$. They also disagreed that neither girl-child education is important (2.02 \pm 0.98$)$ nor seen as an asset (2.02 \pm 0.96$)$. Finally, they disagreed that girl-child education facilitates land ownership (1.98 \pm 0.97$)$. Analysis of question 3 shows that girl-child education does not influence women ownership of land in the study area because the grand mean of 2.03 is less than the criterion mean of 2.5 .

\section{Testing of the Hypothesis}

\subsection{Hypothesis 1}

Girl-child education has no significant association with women technical occupation in Ikot Ekpene LGA 


\begin{tabular}{|c|c|c|c|}
\hline $\mathbf{X}^{\mathbf{1}}$ & Value & $\mathbf{D F}$ & ASYMP. SIG. (2-SIDED) \\
\hline Pearson Chi-Square & $13.714^{\mathrm{a}}$ & 6 & .033 \\
\hline Likelihood Ratio & 14.161 & 6 & .028 \\
\hline Linear-by-Linear Association & .732 & 1 & .392 \\
\hline N of Valid Cases & 576 & & \\
\hline
\end{tabular}

Table 6: Test of Hypothesis 1

Source: Field Survey, 2019

a. 0 Cells (0.0\%) Have Expected Count Less Than 5, The Minimum Expected Count Is 15.67

As shown in table, girl-child education is significantly $(\mathrm{p}<0.05)$ associated with women technical occupation in Ikot Ekpene LGA. The analysis further showed that girl child education is linearly associated $(p<0.05)$ with women technical occupation in Ikot Ekpene LGA. The null hypothesis is rejected, which implies that girl-child education and women technical occupation is significantly related.

\subsection{Hypothesis 2}

Girl-child education has no significant association with women access to credit facilities in IkotEkpene LGA.

\begin{tabular}{|c|c|c|c|}
\hline $\mathbf{X}^{\mathbf{1}}$ & Value & DF & ASYMP. SIG. (2-SIDED) \\
\hline Pearson Chi-Square & $15.821^{\mathrm{a}}$ & 6 & .015 \\
\hline Likelihood Ratio & 16.095 & 6 & .013 \\
\hline Linear-by-Linear Association & 13.838 & 1 & .000 \\
\hline N of Valid Cases & 576 & & \\
\hline
\end{tabular}

Table 7: Test of Hypothesis 2

Source: Field Survey, 2019

a. 0 Cells (0.0\%) Expected Countless Count than 5, Minimum Expected Is 26.67

The Chi-Square table above showed that girl-child education is significantly $(\mathrm{p}<0.05)$ associated with access to credit facilities in Ikot Ekpene LGA. Table 7 further showed that girl-child education is linearly associated ( $<<0.05)$ with access to credit facilities in Ikot Ekpene LGA. The null hypothesis is rejected, which implies that girl child education and access to credit facilities is significantly related.

\subsection{Hypothesis 3}

Girl-child education has no significant association with women ownership of land in Ikot Ekpene LGA?

\begin{tabular}{|c|c|c|c|}
\hline $\mathbf{X}^{\mathbf{1}}$ & Value & DF & ASYMP. SIG. (2-SIDED) \\
\hline Pearson Chi-Square & $6.795^{\mathrm{a}}$ & 9 & .658 \\
\hline Likelihood Ratio & 6.870 & 9 & .651 \\
\hline Linear-by-Linear Association & .934 & 1 & .334 \\
\hline N of Valid Cases & 768 & & \\
\hline \\
Table 8: Test on Hypothesis 3 \\
Source: Field Survey, 2019 \\
a. 0 Cells (0.0\%) Have Expected Count Less Than 5, The Minimum Expected Count Is 20.75
\end{tabular}

Table 8 showed that girl child education is not significantly ( $>>0.05$ ) associated with women ownership of land in Ikot Ekpene LGA. Analysis in Table 8 further showed that girl-child education is not linearly associated ( $p>0.05$ ) with women ownership of land in Ikot Ekpene LGA. The null hypothesis is accepted, which implies that girl-child education and women ownership of land is not significantly related.

\section{Discussions}

The study reveals that there is a positive association between girl-child education and women engagement in technical occupations. Where women are educationally empowered, they are likely to occupy more technical and managerial positions in both private and public organizations. This is in line with Ballara (2002) and Elias (2016), when they observed that educating the girl-child creates chances of gaining access to technical occupation, managerial position and political appointment since education has a direct bearing on economic well-being of individual, family and community. As the girl-child qualifies educationally and grows into a woman, her economic empowerment, contribution to socio-economic development and growth at both local and national levels are visible. She has access to opportunities of engaging good paying jobs, grows to managerial positions and can equally be elected or appointed into political offices. This invariably has positive impact on the level of income, accessibility to credit facilities and also access to land. The study further shows that girl-child educational attainment is the necessary prerequisite that enhances and exposes them to appropriate information pertaining to banking, credit facilities and other related financial services for the promotion of economic empowerment of women. 
This view supports the findings of Ballara, (2002);Ekesionye\& Okolo, (2012);World Bank (2013);WHO (2014) and Fox \& Romero (2017) when they maintained that education gives women access to economic resources, credit facilities and open up socio-economic opportunities for women in various sectors both formal and informal in the society.

The study further reveals that girl-child education and women ownership of land in the study area is not significantly related. This may not be independent of the attitudes and perception of male superiority, preference and domination of woman. This is festered within the cultural and traditional system which advocates patriarchy; hence, such a system places the onus of disciple, regulation, correction and control of assets such as land within the ambit of male authority. This practice promotes the domination and subjugation of the girl-child in all aspects of life. This finding is in line with the findings of Nazet al. (2013) and Udoyen et al. (2017) when they asserted that the control over resources such as land is hindered by discriminatory legal, and customary law provisions which in most cases reinforces gender inequalities as well as social norms and practices, irrespective of women educational attainment.

\section{Planning Implications}

Basically, planning goal centered on the coordination of all form of development activities at both micro and macro levels, maximize opportunities for a healthy living, and create adequate access to basic human needs irrespective of gender. Planning at any level is centered on humans or social elements in relations to human settlement and achieving better quality of life for the community's residents. Planning provide an alternative rationale which can illuminate the process of political economic, cultural and social change action in a more positive and hope-inspiring way for women in the society.

Women are known to be custodian of societies (Olufemi, 2016). They contribute significantly (directly or indirectly) in planning and development of economics and human societies. Therefore, it is imperative that planners at all level be at the forefront of ensuring that there is gender equity and equality in access to basic human needs and services in all areas or endeavour.

In conception, formulation and implementation of community development plans, there is need for attention on how the plan will positively impact multiple publics. Also, in considering community development policy blueprint, women need must be considered as critical for a gendered - conscious planning and development as this will promote both; the process and the product of community development.

Moreso, the findings of the study calls for a consideration of gender - inclusive curriculum in planning schools and other academic departments to help in equipping women with the means to challenge people's exclusionary, narrowminded reasoning on land and property ownership, financial transactions, engagement in technical jobs, addressing the existing gaps in girl-child (women) accessibility to basic human needs and services in the study area, Akwa Ibom State and Nigeria at large.

Since planning, from feminist perspective, involve achieving equal access to opportunities (e.g. employment, school), affordable housing, accessibility to land, social and economic infrastructure and financial services planners need to focus on the diversity of women, their needs - cultural, religions, class and social preferences in the provision of social and economic infrastructure and services in the area.

The findings also for gender-disaggregated data for the purpose of understanding and monitoring setbacks and progress in all effort aimed at promoting women economic empowerment in Akwa Ibom State and other developing societies.

\section{Conclusion and Recommendations}

The contribution of girl-child education to local and national transformation (social and economic) are uncountable. Lack or unequal access to quality education by the girl-child could result in continuous non-utilization of the untap resources/capabilities existing in women. This may result in losses in most sectors of the economy where women are known to perform their best; such as in trading businesses, trading, craft and in leadership positions. It is expedient that the girl-child acquires quality education to enable them achieve and promote women economic empowerment with the ultimate aim of promoting local and national economic development effort.

On the basis of findings or the study, the following recommendations are made:

- The girl-child must be given equal opportunities with boys to explore and harness their limitless potentials. A total re-examination of education of men and women on the ills of inequalities in access to education need to considered.

- There should be awareness creation at communities and religion circles on the implication of some of these obnoxious practices that reduce the female child to a second-class citizen. Social sensitization activities should be encouraged through programmes and trainings on the ills and dangers of these practices.

- Girl-child education should be controlled and supervised by an agency created specifically for girl-child and women education in the study area. Women in technical occupation should be involved in the promotion of girl child education programmes, if they are educated and well placed, they would be able to work with the policy makers in identifying the problems confronting girl-child education and subsequent economic empowerment of women.

- There is also the need for authorities to facilitate unfettered playing field for both men and women in the local and state affairs which should altruist more women into more productive sectors, governance and decision-making organs of the government. It is only when women are adequately educated, liberated and empowered that the society and her agencies can attain meaningful socio-economic development and growth. 
- Furthermore, the implementation of the ongoing free education programmes in the study area and AKS in general should be given adequate attention for the possible realization of economics empowerment of women.

\section{References}

i. Akwa Ibom State (2013). Statistical Year Book of Akwa Ibom State of Nigeria. Directorate of Statistics, Ministry of Economic Development, Uyo, Akwa Ibom State, pp. 2-100.

ii. Ashraf, F. I. (2007). Education and Women's Empowerment: Re-examining the Relationship. Education Gender and Empowerment: Perspectives from South Asia, 18,15-31.

iii. Ballala, M. (2002). Girls and Women Literacy. London: Zed Books Limited, pp. 32-50.

iv. Channawar, S. (2019). Role of Education in Women Empowerment. International Journal of Recent Trends in Engineering and Research, 2 (11), 357-359.

v. Chaudhry \& Rahaman. (2009). The impact of Gender Inequality in Education Rural Poverty in Pakistan. https://www.elf.gov.cy.gender.equality.nsf.all.pdf. Retrieved on 15th November, 2019.

vi. Doreen, K. (2014). The Impact of Girl-Child Education on Community Development: A Study of Ika Local Government Area of Akwa Ibom State. Research on Humanities and Social Sciences, 4 (12), 112 - 127.

vii. Ekesionye, E. N \& Okolo, A. N. (2012). Women Empowerment and Participation in economic activities: indispensable tools for self-reliance and development of Nigerian society. Educational Research and Review, 7(1), 10-18.

viii. Elias, S. (2016). The role of education on empowerment of women in Gorakhpur District. Thesis of the University of Allahabad, India. http://hdl.handle.net/10603/176053. Retrieved on 11th November, 2019.

ix. Fox, L. \& Romero, C. (2017). In the mind, the household, or the market? Concepts and measurement of women economic empowerment. Policy research working paper. www.worldbank.org.wps8079.pdf. Retrieved on $6^{\text {th }}$ October, 2019.

x. Hunt, A \& Samman, E. (2016). Women's economic empowerment: Navigating enablers and constraints. Development Progress, Overseas Development Institute, London, pp. 8-34. https://www.odi.org/publications/10483-womens-economic-empowerment-navigating-enablers-allconstraints.

xi. Huzeru, 1. (2012). The role of Non-governmental organization in girl-child education in Tolon-Kumbungu District of the Northern Region of Alara. http://hal.handle.net/123456789/7614. Retrieved on 16 ${ }^{\text {th }}$ November, 2019.

xii. Lagachu, R. (2016). Education and Woman Rights of missing Tube: A case study on Jengrai Panchayat (Majuli) of Jorhat District, Assain Ranuj Legachu. International Journal of Humanities \& Social Science Studies, 2(5), 261-267.

xiii. Lifanda, K. N. (2005). Education and Training of Women and the Girl-Child. Online Discussion for the Review of Beijing+10, (UNESCO/UNICEF), pp.2030. https://www.un.org/womenwatch/forums/review/Ed u-Training-Women-Girl-child.pdf. Retrieved on 21 ${ }^{\text {st }}$ December, 2019.

xiv. Naz, A., Daraz., U., Mughai, I., Alam, A., Khan, W. and Hussain, M. (2012). Global Journal of Human social science, Linguistics \& Education, 12(13), https://www.reseachgate.net/publiccation/283243260 , Retrieved on 15 th November, 2019.

xv. NBS, (2015). Statistical Report on Women and Men in Nigeria, Abuja.

xvi. NPC, (1991). Population Census of Federal Republic of Nigeria, Analytical Report at the Federal Level. Abuja.

xvii. NPC, (1998). Population Census of Federal Republic of Nigeria, Analytical Report at the Federal Level. Abuja.

xviii. Obot, Napoleon (2006). Akwa Ibom Renaissance: From the Land of Promise to Land of Fulfilment, Uyo, Nigeria: Abam Publishing C0. pp. 20-42.

xix. Ocho, L. O. (2005). Issues and Concerns in Education and Life. Enugu: Institute of Development Studies, University of Nigeria, pp. 29-45.

xx. Offorma, G. (2015). Girl child education in Africa. https://www.researchgate.net. Retrieved on 21 ${ }^{\text {st }}$ October, 2019.

xxi. Offorma, G. C. (2009). Girl child education in Africa. Keynote Address President at the conference of the University Women of Africa held in Lagos, Nigeria. 16-19 July.O' Neil, T. Domingo, P. \&Valters, C. (2014). Progress on Women's Empowerment: From technical fixes to political action. Development Progress Working Paper. London. https://www.odi.org.uk/files/odi-assets/publications-opinion-files/9282.pdf. Retrieved on 24th December, 2019.

xxii. Udofia, E. (2011). Applied Statistics with Multivariate Methods. Enugu: Immaculate Publications Limited, pp. 25-62.

xxiii. Udoyen, G. J, M. Ifeeanacho, \& A. Ufot-Akpabio. (2017). Patriarchy and Intimate Partner Violence in the Nigeria Delta Region of Nigeria. International Journal of Social Sciences, 11 (1), 82 - 95.

xxiv. UNESCO (2013). Education for all: Global Monitoring Report https://en.unesco.org.girls-factsheets.en.pdf. Retrieved October, 2019.

xxv. UN (2013). The role of women in rural development, food production and poverty eradication. www.unwomen.org.infocus.2013. Retrieved on 6 $6^{\text {th }}$ October, 2019.

xxvi. United Nations Children Education Fund (2015). Girl's education and gender equality. http://www.unicef.org/education/beye-70640. Html. Retrieved on $16^{\text {th }}$ November, 2019. 
xxvii. World Bank (2013). 'Promoting Youth Entrepreneurship and Employment: The Case of Low PDR' Adolescent Girls Initiative (AGI) result series. Washington, DC. http://documents.worldbank.org/curated/en/2 013/07/18397990/promoting-youth-enterpreneurship-employment-case-loe-pdr. Retrieved on 29th December, 2019

xxviii. World Bank (2014). Education Plays Key Role in Advancing Women, Girls, and Communities. www.worldbankorg/en/news/press-release/2014/05/14/education.key-role-women-girls-communitiesreport.Retreieved on 16th November, 2019. 